\title{
New Danish law: human life begins at conception
}

\author{
Søren Holm University of Copenhagen
}

\section{Author's abstract}

A new law has been passed by the Danish Parliament, establishing an ethical council. The law has caused considerable debate in Denmark, particularly because it states that 'the work of the council shall build on the basis that human life takes its beginning at the time of conception'.

\section{Introduction}

On the 22 of May 1987 the Danish Parliament passed a new Bill aimed at the solution of the ethical and societal problems inherent in the new reproductive technologies which have evolved in the last few years. The law establishes, for the first time in Denmark, an ethical council which shall propose legislation and it puts a temporary ban on some aspects of the new technologies until appropriate legislation has been passed. Other aspects of the reproductive technologies are totally prohibited (1).

\section{The history of the law}

In the last few years there has been increasing public interest and awareness concerning the ethical problems that have arisen with the new reproductive technologies such as in vitro fertilisation (IVF) and genetic engineering. This has been seen all over Europe but in Denmark the debate was minimal until 1984-85, when it spread rapidly in the media. This prompted the Government to propose a Bill in 1985 which called for the formation of an ethical council. All parties in the parliament agreed in principle, but the process was stopped, because the Christian People's Party, which is part of the Government, demanded that the law should declare that 'human life begins at conception'. This phrase was included in the original proposal, but the other Government parties were reluctant to pass a law containing this statement and since the main opposition party (the Social-Democratic party) was also against it, the law was not passed before the summer recess. During the recess the Christian

\section{Key words}

Medical ethics; medical law; human beings.
People's Party 'twisted the arm' of its fellows in the Government and the statement on the beginning of human life was included when the Bill was reproposed ? in the new sitting. This caused considerable debate, and was protested against several times by the Danish 을 Medical Association (Lægeforeningen) (2). However, thanks to the votes of the Government parties and the more radical socialist parties the Bill was passed.

\section{The ethical council}

The ethical council consists of 17 non-professional members (with a sex-ratio of $9 / 8$ ) and can call upon any experts it wants to hear. The council is supposed to propose legislation in a number of areas including:

1. The use of fertilised eggs and living fetuses for research.

2. Genetic treatment of human germ cells, fertilised eggs, embryos and fetuses.

3. The use of new methods in prenatal diagnosis.

4. The possibilities of storing human germ cells and fertilised eggs.

But the council is also free to discuss any other subject in connection with medical ethics and it is supposed to guide the research-ethical committees which have been formed to implement the Helsinki-II declaration. It is explicitly stated that the council shall inform the public $\frac{7}{0}$ and ensure that the ethical problems are debated in public, for instance through public hearings. This or gives the ethical council some of the potential of an $N$ independent agency and it may acquire a position in Denmark not unlike that enjoyed by the now dissolved 'President's commission for the Study of Ethical Problems in Medicine and Biomedical and Behavioral Research' in the USA (3).

\section{The prohibitions}

The law contains three explicit prohibitions, it prohibits:

1. Experiments aimed at cloning human beings.

2. Experiments aimed at producing human/human mosaics.

3. Experiments aimed at producing human/animal $\stackrel{ }{\rightleftharpoons}$ 
chimerae, or by genetic engineering, producing humans with partly non-human genetic components.

The inclusion of these prohibitions was also opposed by the Medical Association, which stated that such prohibitions should only be implemented following international agreement by the medical profession, for instance through the Comite Permanent of the Medical Associations in the EEC (2).

\section{Controversies and consequences}

The law contains at least two controversial points. The first is the above mentioned statement that "human life begins at conception'. In the debate it was connected to the issue of abortion and those opposed to its inclusion in the law saw it as the first step towards a prohibition of abortion. It was also claimed that matters of biological fact should not be included in legislation. The consequences of this statement in the law, with regards to abortion, IVF, experiments on fertilised eggs etc, are not yet clear and its importance and significance is very closely related to the question whether human life or personal life is the important factor in deciding ethical and moral status $(4,5)$. The importance of the statement, as a meaningful 'ethical' statement, might be eroded if we see a major shift in the public opinion from human to person as the deciding factor.

The other controversial point is the temporary prohibition of experiments on 'spare' fertilised eggs following IVF. The law states that such experiments are prohibited until the ethical council has proposed a Bill and it has been passed in Parliament. The ethical council was assembled in the Spring of 1988, and was requested to make proposals for a Bill to be put before Parliament in the 1989-90 session: this means an effective 1-3 year prohibition of these experiments. Researchers in the field have called it a major drawback, and have claimed it will prevent the optimisation of IVF treatments.

\section{Discussion and conclusion}

With this new law the Danish Parliament has finally acknowledged the need for regulation of the new reproductive technologies. Denmark has long traditions of self-regulation by the medical associations but through this debate it has become clearly evident that the public perceives the new technologies to be so threatening that their regulation could not be left to the discretion of the medical profession. The same process is proceeding in most countries in the world, probably also assisted by a general diminishing of the trust in medical authorities. This process has been very slow in Denmark, but is now gaining momentum, and one can only hope that the public's interest and understanding in medical ethics will grow along with its distrust of medical authorities. The new law does not solve any ethical problems but it has provided the means by which the most urgent problems can be discussed and made public and a public policy decided with the participation of all parts of society.

\section{Acknowledgment}

Søren Holm is supported by a grant from Michaelsen Fonden.

Søren Holm is a fifth-year medical student at the University of Copenhagen and is presently on a Michaelsen Fonden scholarship at the university's Institute of Neurophysiology. He has received the silver medal of the University of Copenhagen for a dissertation on The ethical problems in prenatal diagnosis (in Danish). Address: Søren Holm, Institute of Neurophysiology, Panum Institute, Blegdamsvej 3C, $2200 \mathrm{~N}$, Copenhagen, Denmark.

\section{References}

(1) Lov om oprettelse af et etisk räd og regulering af visse biomedicinske forsøg. Lov nr L76 af 22 maj 1987.

(Law on the establishment of an ethical council and on regulation of certain biomedical experiments. Law nr L76 of 22 May 1987.)

(2) Lægeforeningens Hovedbestyrelse. Skrivelse af 14.III.1986 til Udvalget vedrørende oprettelse af et etisk räd og regulering af visse biomedicinske fors $\varnothing \mathrm{g}$ (in Danish). Ugeskrift for Læger, 1986; 148: 730-731.

(3) The President's Commission for the Study of Ethical Problems in Medicine and Biomedical and Behavioral Research. Report: Summing Up. Washington DC: Government Printing Office, 1983.

(4) Engelhardt H T. The foundations of bioethics. New York: Oxford University Press, 1986.

(5) Holm S. The peacable pluralistic society and the question of persons. The Fournal of medicine and philosophy, (in press). 